\title{
ERYTHEMA MARGINATUM (RHEUMATICUM)
}

\author{
BY \\ C. BRUCE PERRY, M.D., F.R.C.P. \\ (Professor of Medicine, University of Bristol.)
}

\section{Historical survey}

At the International Medical Congress held in London in 1881 Barlow and Warner $^{2}$ read a paper on subcutaneous nodules in rheumatism and chorea in which they stated that of twenty-seven children with nodules ten had skin eruptions in eight of whom the rash was an erythema marginatum or papulatum. Barlow ${ }^{3}$ later stressed the occasional occurrence of erythema marginatum at the onset of, or during the course of acute rheumatism.

In his classical monograph on the Rheumatic State in Childhood, Cheadle $^{5}$ classes an exudative erythema-erythema marginatum-as one of the specific manifestations of the rheumatic state in childhood, and he illustrates the typical rash by a drawing of a child who also showed a heavy crop of nodules. Cockayne ${ }^{7}$, however, points out that the association between skin lesions and acute rheumatism was first described by Rayer in 1835. Poynton and Paine ${ }^{18}$ described cutaneous manifestations of rheumatism which in many cases resembled tinea circinatum or erythema iris, and which may appear before the full picture of the disease has developed, during the attack, or as an almost solitary incident between definite attacks. Apart from these two papers little attention appears to have been paid to the condition recently until Lehndorff and Leiner ${ }^{13}$ described the typical erythema marginatum under the title of erythema annulare. This may have been because erythema nodosum was for many years considered as a cutaneous manifestation of rheumatism, although it is interesting to note that Barlow was doubtful of this when he described the erythema marginatum in 1883. Since the paper by Lehndorff and Leiner, in which they stated that the eruption was a specific manifestation of acute rheumatism, several descriptions of the rash have appeared in the continental journals. (Chester and Schwartz $^{6}$, Lehndorff ${ }^{12}$, Leichtentritt ${ }^{14}{ }^{15}$, Walgren ${ }^{20}$ ), and to these authors has been given the credit for first describing the condition. In fact, $\mathbf{A b t}^{1}$ appears to be the only author of recent years who has given Barlow and Cheadle credit for the original description. All of the authors quoted regarded the eruption as occurring only in rheumatic patients, but Swift ${ }^{19}$ states that a similar rash may be seen in other infections. Goodall and Washbourn ${ }^{11}$ describe an erythema marginatum or circinatum occurring in serum sickness and Davidson ${ }^{8}$ suggested that the marginate erythema of serum sickness might be due to the albumin fraction 
while urticaria and the morbilliform eruption were due to euglobulin and pseudo-globulin respectively. Debré ${ }^{9}$ states that the rheumatic erythema annulare must be distinguished from the aberrant erythema marginata sometimes seen in serum sickness and from the rash of ' fifth disease.'

Many estimates of the frequency with which this eruption is found have been given. Leichtentritt ${ }^{14}$ on a basis of ten cases states that it occurs in 62.5 per cent. of cases of rheumatic infection in childhood. Chester and Schwartz ${ }^{6}$ describe it as occurring in ten cases out of twenty-one cases of acute rheumatism seen in an epidemic. Walgren ${ }^{20}$ states that he has seen it in about 12 per cent. of cases (18 out of 146 children with acute rheumatism) and Lehndorff ${ }^{12}$ estimates that it occurs in 10 per cent. of cases at the most. $\mathbf{A b t}^{1}$ found that at the Spaulding School erythema was more common than nodules. Cockayne found rashes in 4.23 per cent. of children with chorea and in 4 per cent. of those with acute rheumatism. In the same series nodules occurred in 7 and 10 per cent. respectively. Maddox ${ }^{17}$ in a study of 428 children with acute rheumatism in Sydney found sixty cases with rashes (14 per cent.); of these sixteen are described as ' morbilliform-erythema marginatum' and thirty-three were ' unclassified.' It is probable that the majority of these were also erythema marginatum.

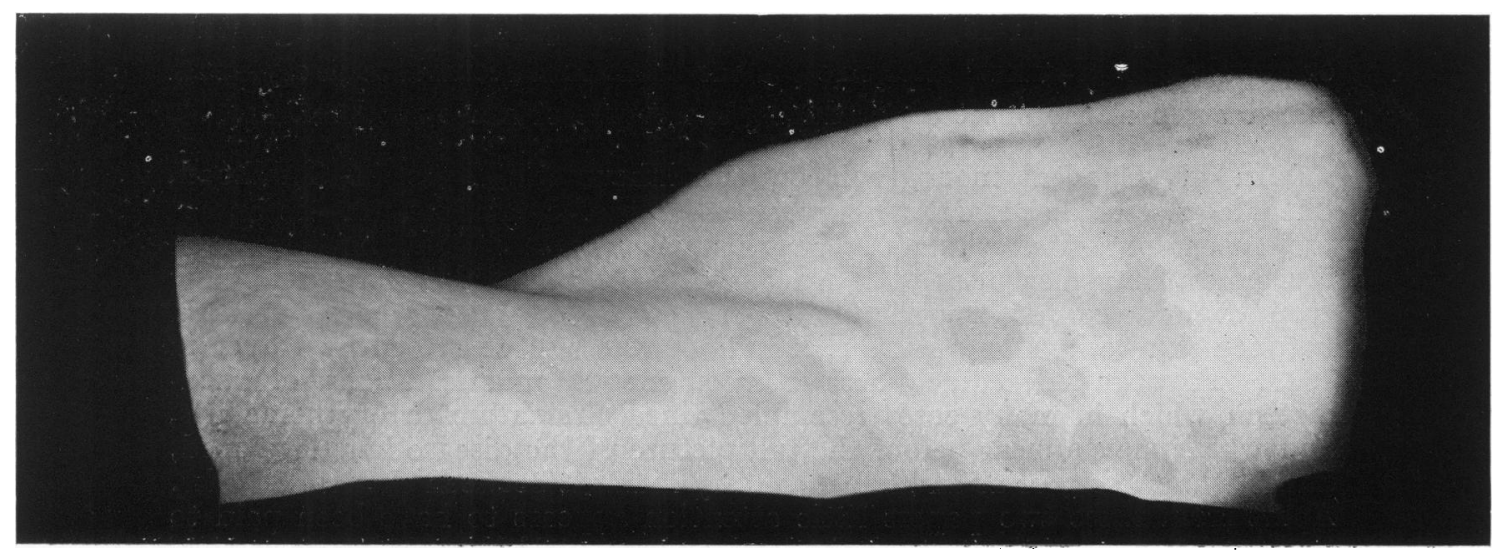

FIG. 1. - Showing the early stage of 'solid' erythema just beginning to spread out.

\section{Present series}

During the past five years I have paid special attention to this eruption but it has never been seen except in patients with other evidence of rheumatic infection and it appears to be a specific rheumatic manifestation. In Bristol it is comparatively rare, and only thirteen cases have been seen, all children under the age of sixteen and it is less frequent than nodules. Characteristically the eruption starts as a solid erythema (fig. 1), little, if at all, raised. It gradually spreads out and as it does so the skin in the centre of the lesion returns to normal, thus forming the typical 
spreading marginate or annular eruption (fig. 2). Where the spreading circles of rash meet they coalesce forming a larger ring (fig. 3). This suggests the possibility that the skin in the middle of the lesion might have become refractory to the irritant and thus could not respond again to the stimulus reaching it from a neighbouring eruption. In other words, that the rash was similar to the annular oedema described by Lewis and Zotterman $^{16}$ in a case of bacterial endocarditis. However, the skin inside the erythema has been tested in several cases and in all it reacted to light and heavy stroking, and to histamine, in exactly the same way as the skin outside. In only one case, in which the rash was very well marked, the inside edge of the erythema was slightly raised and oedematous. Carol and

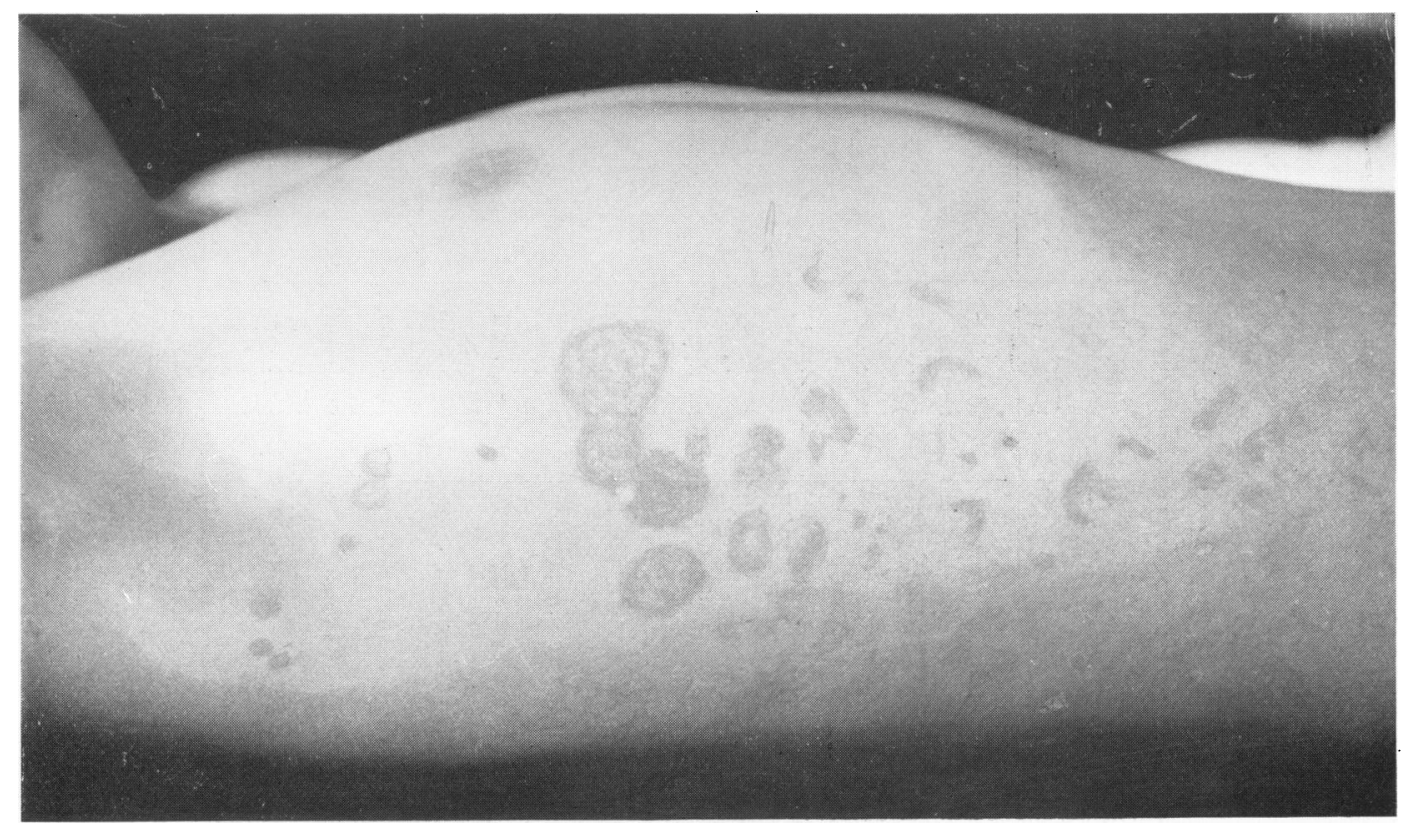

FIg. 2.-Showing the later stage of the eruption-the typical 'erythema marginatum' or 'annulare.'

Krieken ${ }^{4}$ performed a biopsy on one typical case and report that histologically the rash appeared to be an acute inflammation of the outer and middle layers of the cutis with a well-marked polymorphonuclear leucocytic infiltration. Debré, Lamy and Jammet ${ }^{10}$ believe that the rash only develops in those severe cases of acute rheumatism with a streptococcus viridans bacteraemia. (These authors consider that there is no clear cut distinction between acute rheumatism and endocarditis lenta.)

The usual sites of its occurrence are on the front of the abdomen and on the front and back of the chest; it may develop on the limbs, but I have never seen it on the face. 


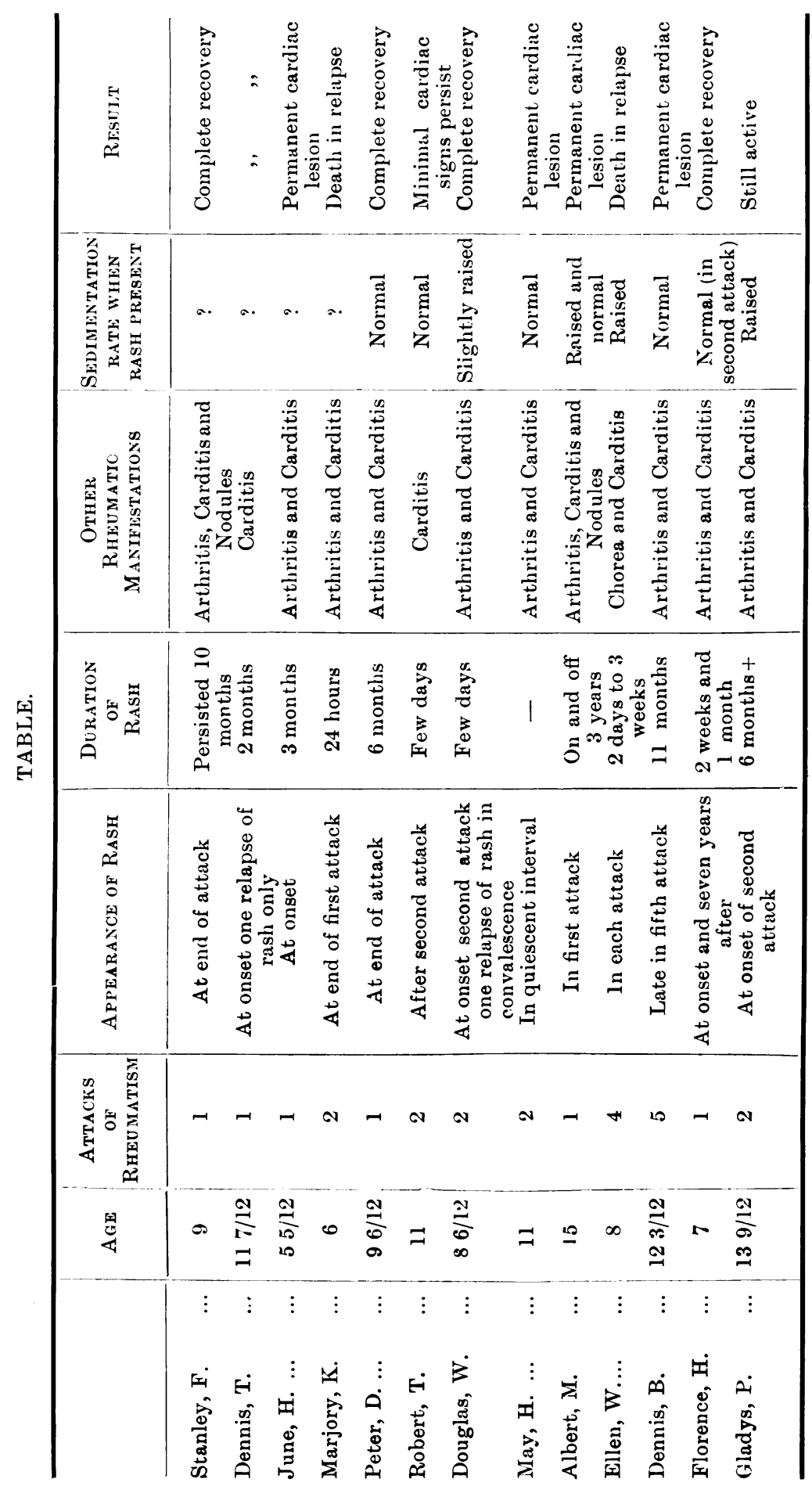


It may, and usually does, appear at the onset of an acute attack or relapse of rheumatism but it is frequently present when there are no other signs of active infection and when the sedimentation rate is normal. Once it has occurred it tends to come and go lasting from one or two days to months or years. In five of the present series of cases it was seen whenever the child was examined for from six months to three years after all other evidence of activity had disappeared (see table). This has been noted by others, and Walgren on account of this phenomenon has suggested that the


FIG. 3.-Tracings of the same area made at 10.30 a.m., 11.30 a.m, 2 p.m. and 3.30 p.m. on the same day, showing the spread of the rash and the way in which the circles fuse on meeting.

rash may be ' an angio-neurosis arising on a rheumatic allergic basis in certain highly susceptible individuals.' In one case of acute rheumatism with carditis running a polycyclic course the rash in the acute phase appeared to be most intense when the other manifestations were subsiding or were at a minimum. In only two patients was the rash present at the same time as nodules.

Although the rash may last for many months yet from these few cases it would appear that the development of the rash would tend to indicate a good prognosis as regards the actual rheumatic lesions since in four of the thirteen cases all abnormal cardiac physical signs have disappeared. 


\section{Summary}

(1) Erythema marginatum is a specific manifestation of acute rheumatism.

(2) This eruption usually first appears at the onset of a rheumatic attack or relapse but may continue long afer all other evidence of rheumatic activity has disappeared.

\section{REFERENCES}

1. Abt, A. F., Am. J. Med. Sci., Philadelphia, 1935, CXC, 824.

2. Barlow, T., \& Warner, E., Internat. Med. Cong. Trans., London, 1881, IV, 116.

3. Barlow, T., Brit. Med. J., London, 1883, ii, 509.

4. Carol, W. L. L., \& Krieken, J. A., Acta paediat., Stockholm, 1935, XVII, 372.

5. Cheadle, W. B., ' Rheumatic State in Childhood,' London, 1889.

6. Chester, W., \& Schwartz, S. P., Am. J. Dis. Child., Chicago, 1934, XLVIII, 69.

7. Cockayne, E. A., Arch. Middlesex Hosp., London, 1912, XXVIII, 28.

8. Davidson, W. T. G., Glasgow Med. J., Glasgow, 1919, XCI, 321.

9. Debré, R., Presse méd., Paris, 1936, LXXXIII, 1613.

10. Debré, R., Lamy, M., \& Jammet, M. L., loc. cit.

11. Goodall, E. W., \& Washbourn, J. W., 'Infectious Diseases,' third edition, London, 1928.

12. Lehndorff, H., Wien. med. Wchnschr., Vienna, 1930, CLXXX, 1449.

13. Lehndorff, H., \& Leiner, C., Ztschr. f. Kinderh., Berlin, 1922, XXXII, 46.

14. Leichtentritt, B., Ergebr. d. inn. Med. u. Kinderh., Berlin, 1930, XXXVII, 1.

15. Idem, Pfaundler, M., \& Schlossman, A., 'Diseases of Children,' Philadelphia, 1935, III, 359.

16. Lewis, T., \& Zotterman, Y., Heart, London, 1926, XIII, 193.

17. Maddox, K., Med. J. Australia, Glebe, 1937, i, 499.

18. Poynton, F. J., \& Paine, A., ' Researches on Rheumatism,' London, 1913, 420.

19. Swift, H. F., in Cecil, R. L., Text Book of Medicine, third edition, 1933, 89.

20. Walgren, A., Acta paediat., Stockholm, 1935, XVII, 447. 